\title{
Physical Properties of Peanut and Soy Protein-Based Emulsion Gels Induced by Various Coagulants
}

\author{
Shaobing Zhang * (D), Yushan Jiang, Shuyan Zhang and Lin Chen \\ College of Food Science and Engineering, Henan University of Technology, Zhengzhou 450001, China; \\ 201892062@stu.haut.edu.cn (Y.J.); 18336466993@163.com (S.Z.); linchen11251216@163.com (L.C.) \\ * Correspondence: shaobingzhang@126.com
}

check for updates

Citation: Zhang, S.; Jiang, Y.; Zhang, S.; Chen, L. Physical Properties of

Peanut and Soy Protein-Based

Emulsion Gels Induced by Various

Coagulants. Gels 2022, 8, 79. https://

doi.org/10.3390/gels8020079

Academic Editors: Bao Zhang

and Long Chen

Received: 9 January 2022

Accepted: 25 January 2022

Published: 26 January 2022

Publisher's Note: MDPI stays neutral with regard to jurisdictional claims in published maps and institutional affiliations.

Copyright: () 2022 by the authors Licensee MDPI, Basel, Switzerland. This article is an open access article distributed under the terms and conditions of the Creative Commons Attribution (CC BY) license (https:/ / creativecommons.org/licenses/by/ $4.0 /)$.

\begin{abstract}
Emulsions of peanut and soy proteins, including their major components (arachin, conarachin, glycinin and $\beta$-conglycinin), were prepared by ultrasonication ( $300 \mathrm{~W}, 20 \mathrm{~min}$ ) at a constant protein concentration $(4 \%, \mathrm{w} / \mathrm{v})$ and oil fraction $(30 \%, \mathrm{v} / \mathrm{v})$. These emulsions were then induced by $\mathrm{CaCl}_{2}$, transglutaminase (TGase) and glucono- $\delta$-lactone (GDL) to form emulsion gels. The optimum coagulant concentrations were obtained for peanut and soy protein-stabilized emulsion gels, such as $\mathrm{CaCl}_{2}(0.15$ and $0.25 \mathrm{~g} / \mathrm{dL}$, respectively), TGase $(25 \mathrm{U} / \mathrm{mL})$ and GDL $(0.3 \%$ and $0.5 \%, \mathrm{w} / \mathrm{v}$, respectively). For the $\mathrm{CaCl}_{2}$-induced emulsion gels, the hardness of the $\beta$-conglycinin gel was the highest, whereas that of the conarachin gel was the lowest. However, when TGase and GDL were used as coagulants, the strength of the conarachin emulsion gel was the best. For the GDL-induced emulsion gels, microstructural analysis indicated that the conarachin gel showed more homogeneous and compact structures. The gelation kinetics showed that the storage modulus ( $\left.G^{\prime}\right)$ of all the GDL-induced emulsions increased sharply except for the arachin-stabilized emulsion. The interactive force nature varied between conarachin and arachin emulsion gels. This work reveals that peanut conarachin could be used as a good protein source to produce emulsion gels when suitable coagulants are selected.
\end{abstract}

Keywords: peanut proteins; soy proteins; conarachin; arachin; emulsion gel

\section{Introduction}

Emulsion gels have a certain mechanical strength filled with emulsion droplets. They can be used as fat substitutes or as delivery systems to embed bioactive substances to improve chemical stability [1,2]. According to the different gel matrices, emulsion gels can be divided into protein-based emulsion gels, polysaccharide-based emulsion gels and mixture-based emulsion gels. Protein-based emulsion gels are generally prepared through two-stage processes: first, the preparation of protein emulsions, and then, the gelation of the emulsions induced by heat, acid, salt or enzymes [3]. There are many factors affecting the textural properties of protein-based emulsion gels, and the preparation method of protein emulsions is one of them. In our previous study, we found that compared with highpressure homogenization, the peanut protein emulsion prepared by the ultrasonic method had improved strength and microstructure after gelation [4]. Additionally, Hu et al. [5] successfully prepared a low oil emulsion gel stabilized by defatted Antarctic krill protein using one-step ultrasound. When whey protein [6] and soy protein [7] solutions were pretreated by ultrasound, followed by preparation of emulsion gels, better texture properties were obtained. These studies have indicated that ultrasonic technology has excellent application potential in the preparation of protein-based emulsion gels.

In addition to the preparation method of protein emulsions, protein composition significantly affected the physicochemical properties of emulsion gels. For example, increasing the soy glycinin content progressively increased the gel stiffness, but significantly decreased the water-holding capacity (WHC). Confocal laser scanning microscopic observations showed that increasing glycinin content led to the formation of emulsion gel 
network with a more inhomogenous and porous microstructure [8]. Protein composition had a major influence on gel strength, with the strongest emulsion gels being formed at an optimized protein composition $(0.5 \mathrm{wt} \%$ whey protein and $1.5 \mathrm{wt} \%$ lactoferrin) [9]. At fixed total protein content, higher denatured whey protein contents contributed to gels with higher mechanical properties, e.g., fracture stress, Young's modulus and storage modulus $\left(G^{\prime}\right)$ [10]. Emulsion gels with whey protein isolate at the interface had the highest gel strength (fracture stress and storage modulus), followed by the gels with sodium caseinate, soy protein isolate (SPI), lactoferrin at the interface [11].

Peanut proteins are another important plant protein in addition to soybean proteins, but compared with soybean proteins, the functional properties of peanut proteins are far from being explored, which has seriously limited the applications of peanut proteins in the food industry. Peanut proteins contain two major components: arachin and conarachin. The ratio of arachin to conarachin varies from 0.80 to 1.68 depending on the cultivar of peanuts [12]. Arachin contains two molecular species of arachin, I and II, which possess the same subunit compositions but various molecular weights, 180,000 and 350,000, respectively [13]. Conarachin contains conarachin I and conarachin II, which have different subunit compositions and molecular weights [14]. Monteiro and Prakash [15] compared the functional properties of total protein, arachin, conarachin I, and conarachin II from peanuts, including solubility, water absorption capacity, fat absorption capacity, emulsifying properties, and foaming properties. Liu, Zhao, and Su [16] reported that conarachin had a better emulsifying activity index, foam capacity and heat-induced gelation properties than arachin, while arachin had a higher denaturation temperature, more compacted tertiary conformation and lower surface hydrophobicity than conarachin. Feng et al. [17] found that conarachin and the acid subunits of arachin were more effectively crosslinked by transglutaminase (TGase) than the base subunits of arachin. After TGase treatment, the solubility of both the arachin- and conarachin-rich fractions decreased, and the thermal $T_{\mathrm{d}}$ of the conarachin-rich fraction significantly increased. More recently, Sun, Zhang, Zhang, Tian, and Chen [18] pointed out that ultrasound-assisted extraction could change the arachin composition and structure, thereby improving its emulsifying properties. Hu, Amakye, He, Wang, and Ren [19] reported that both microfluidization and TGase could effectively unfold the structures of arachin and conarachin, increase the exposed free sulfhydryl (SH) content and surface hydrophobicity, and enhance the emulsion stability. Although some structural and functional properties of peanut protein components have been revealed by the above work, little has been studied regarding the preparation and characterization of arachin/conarachin-stabilized emulsion gels.

In this work, emulsions of peanut and soy proteins, including their components, were prepared by ultrasonic methods, and then, the emulsions were further induced by salt $\left(\mathrm{CaCl}_{2}\right)$, TGase and acid (glucono- $\delta$-lactone, GDL) to form emulsion gels. The texture, WHC, dynamic rheological properties and microstructure of different emulsion gels were investigated and compared. Partial structural characteristics of these proteins were analyzed to explore their effects on the emulsion gel properties. This study will promote the understanding of the physical properties of peanut and soybean protein-based emulsion gels induced by various coagulants.

\section{Results and Discussion}

\subsection{Emulsion Characteristics}

Based on our previous work [4], the optimal ultrasound conditions (300 W, 20 min) with a constant protein concentration $(4 \%, \mathrm{w} / \mathrm{v})$ and oil fraction $(30 \%, \mathrm{v} / \mathrm{v})$ were selected to prepare emulsions in this study. As shown in Figure 1, among all protein emulsions, the peanut arachin emulsion had the largest particle size $(2.79 \mu \mathrm{m})$, while the soybean $\beta$-conglycinin emulsion had the smallest particle size $(1.36 \mu \mathrm{m})$, which means that $\beta$-conglycinin possessed the strongest emulsifying activity. Regardless of peanut or soybean proteins, the particle size of their low molecular weight fraction-stabilized emulsion was smaller than that of the high molecular weight fraction emulsion. This may be 
because the low molecular weight protein fractions (such as conarachin and $\beta$-conglycinin) can diffuse to the oil-water interface more quickly, preventing the secondary aggregation of oil droplets and resulting in a smaller emulsion particle size. As shown in Figure 2, the $\Gamma$ of the arachin emulsion was the smallest $\left(1.96 \mathrm{mg} / \mathrm{m}^{2}\right)$, whereas that of the SPI emulsion was the largest $\left(4.20 \mathrm{mg} / \mathrm{m}^{2}\right)$. Puppo et al. [20] reported a $\Gamma$ value of $3.03 \mathrm{mg} / \mathrm{m}^{2}$ in an SPI emulsion. The difference was probably caused by various emulsifying methods. In our work, ultrasonic treatment likely facilitated the interfacial adsorption of SPI during emulsification. Moreover, Figure 2 shows that the $\Gamma$ values of SPI and its components were significantly higher than those of peanut proteins isolate (PPI) and its components, which indicated that the interfacial adsorption capacity of soybean proteins was stronger than that of peanut proteins.

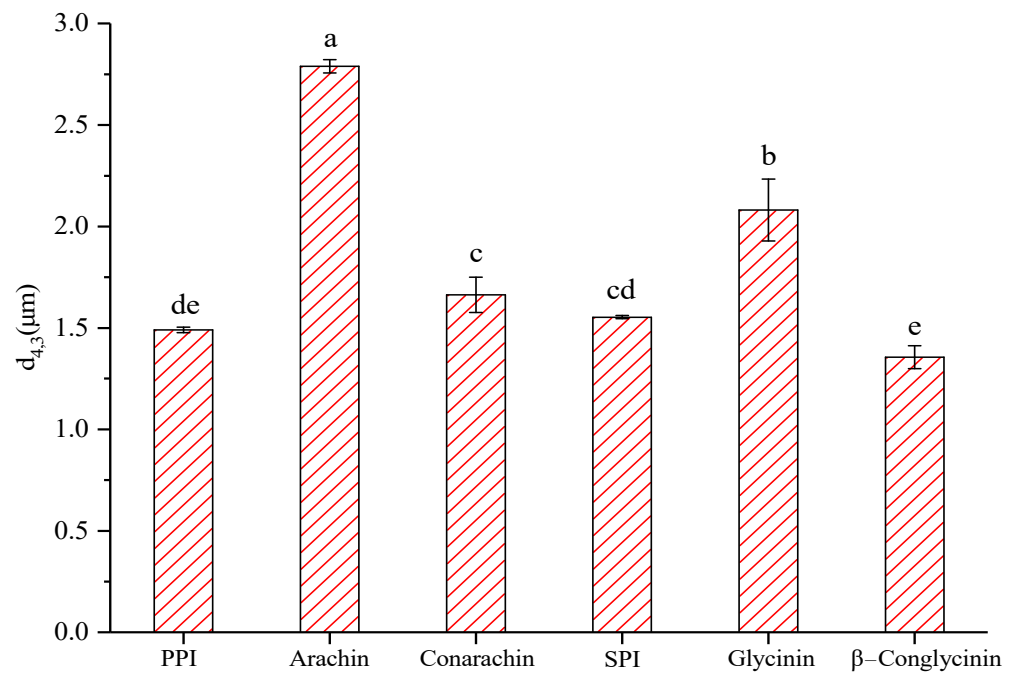

Figure 1. The particle size $\left(d_{4,3}\right)$ of fresh emulsions stabilized by different proteins. The results are expressed as means and standard deviations of three replicates. Bars with different letters indicate significant differences $(p<0.05)$.

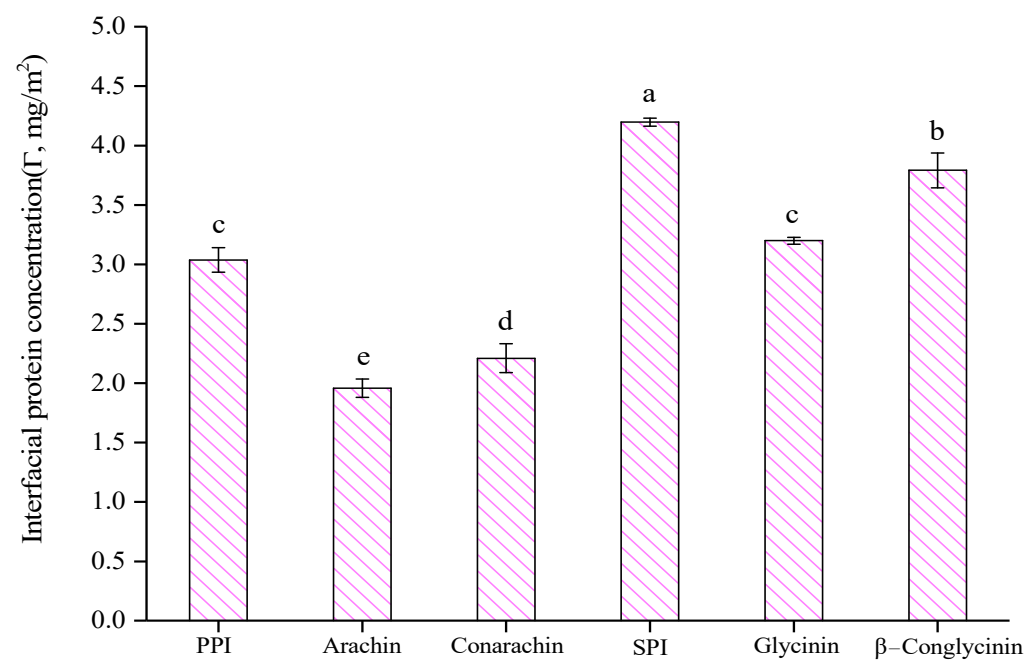

Figure 2. The surface protein concentration $(\Gamma)$ of fresh emulsions stabilized by different proteins. The results are expressed as means and standard deviations of two replicates. Bars with different letters indicate significant differences $(p<0.05)$.

\subsection{Effect of $\mathrm{CaCl}_{2}$ Concentration on Hardness and WHC of PPI and SPI Emulsion Gels}

$\mathrm{CaCl}_{2}$, as a divalent salt at appropriate concentrations, can not only screen the repulsive forces between protein molecules but also induce the crosslinking of proteins and thus promote gelation. The amount of salt used to form an emulsion gel is a major factor in 
determining the gel structures. Figure $3 \mathrm{~A}$ shows that with increasing $\mathrm{CaCl}_{2}$ concentration, the hardness of the PPI emulsion gel increased slightly at the beginning and then decreased sharply, while the WHC was gradually reduced. The optimum $\mathrm{CaCl}_{2}$ concentration was $0.15 \mathrm{~g} / \mathrm{dL}$. Figure 3B shows that the hardness of the SPI emulsion gel was gradually enhanced with increasing $\mathrm{CaCl}_{2}$ until its concentration reached $0.25 \mathrm{~g} / \mathrm{dL}$, and the gel hardness then decreased slightly. The same trend was observed for the WHC of the SPI emulsion gel. By comparison, the gel hardness and WHC of the PPI emulsions were significantly lower than those of SPI emulsions at the same $\mathrm{CaCl}_{2}$ concentrations (except $0.1 \mathrm{~g} / \mathrm{dL})$.

$\mathbf{A}$

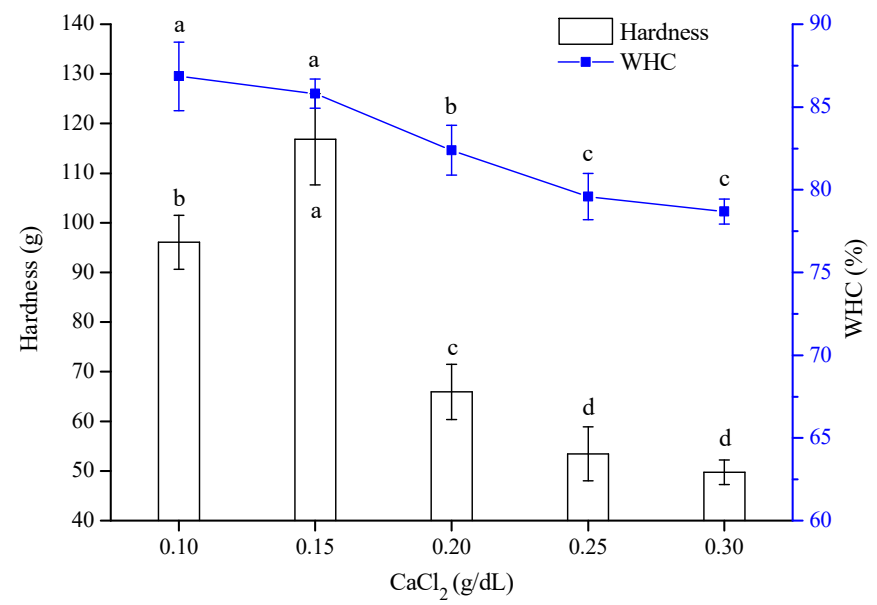

B

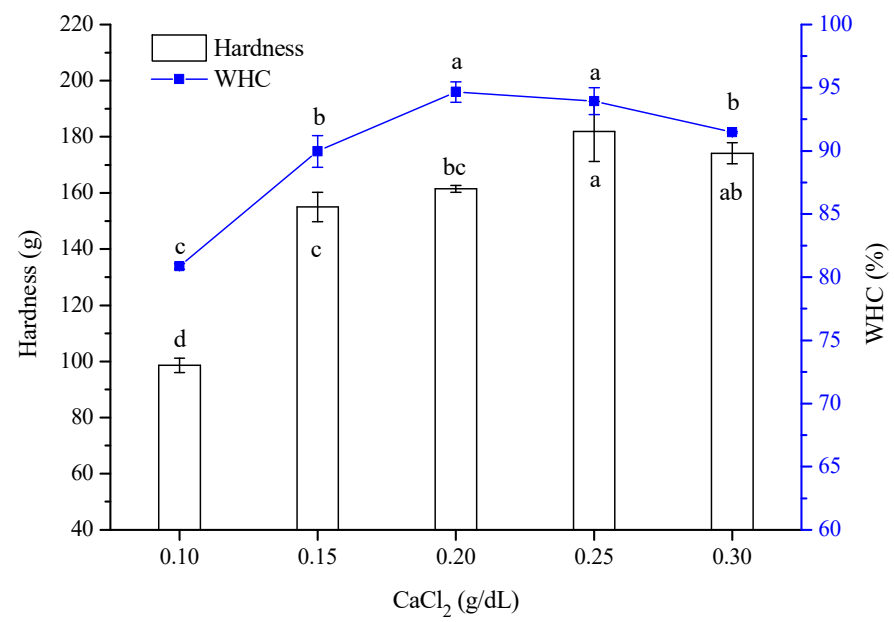

Figure 3. Effect of $\mathrm{CaCl}_{2}$ concentration on hardness and WHC of PPI (A) and SPI (B) emulsion gels. The results are expressed as means and standard deviations of two replicates. Bars with different letters indicate significant differences $(p<0.05)$.

The above results indicated that $\mathrm{CaCl}_{2}$ at higher concentrations was not favorable for the gelation of PPI and SPI emulsions. Sok Line, Remondetto, and Subirade [21] found that low $\mathrm{Ca}^{2+}$ concentrations induced $\beta$-lactoglobulin emulsion gels with a fine-stranded structure, while high $\mathrm{Ca}^{2+}$ concentrations (such as $68 \mathrm{mM} \mathrm{Ca}^{2+}$ ) reduced the WHC and changed the structure of the emulsion gel from fine-stranded to random aggregates. Wang et al. [22] reported that the storage modulus $\left(\mathrm{G}^{\prime}\right)$ of SPI emulsion gels increased gradually with increasing $\mathrm{Ca}^{2+}$ concentration $(2.5-7.5 \mathrm{mM})$ but decreased at $10 \mathrm{mM}$. The decrease in hardness and WHC at higher $\mathrm{Ca}^{2+}$ concentrations was probably attributed to random protein aggregation, which led to extremely large protein aggregates forming porous gel structures [21]. It is worth noting that compared with the SPI emulsion gel, the textural 
deterioration of the PPI emulsion gel was more dramatic at higher $\mathrm{Ca}^{2+}$ concentrations, suggesting that the aggregation of PPI might be more sensitive to the $\mathrm{Ca}^{2+}$ concentration.

\subsection{Effect of TGase Concentration on Hardness and WHC of PPI and SPI Emulsion Gels}

TGase can catalyze the crosslinking of lysine and glutamine residues on protein molecules, whose strength far exceeds that of hydrophobic interactions and hydrogen bonds [23]. Therefore, this enzyme is widely used in the preparation of cold-set protein gels or emulsion gels. As shown in Figure 4, the hardness and WHC of the PPI and SPI emulsion gels increased with increasing TGase concentration (from 10 to $25 \mathrm{U} / \mathrm{mL}$ ), suggesting that a more elastic network was developed at higher TGase concentrations. At an appropriate enzyme concentration $(25 \mathrm{U} / \mathrm{mL})$, both the hardness and $\mathrm{WHC}$ reached the highest values. However, excessive crosslinking between the protein molecules might result in the expulsion of water from the emulsion gels and subsequent textural deterioration. At the same enzyme concentration, the hardness of the PPI emulsion gel was significantly lower than that of the SPI emulsion gel, whereas their WHCs remained similar (Figure 4). In a recent study, Alavi, Emam-Djomeh, Salami, and Mohammadian [24] reported that the hardness of egg white protein gels and emulsion gels increased considerably when TGase increased from 0 to $20 \mathrm{U} / \mathrm{g}$. A higher enzyme concentration was not used in their work.

A

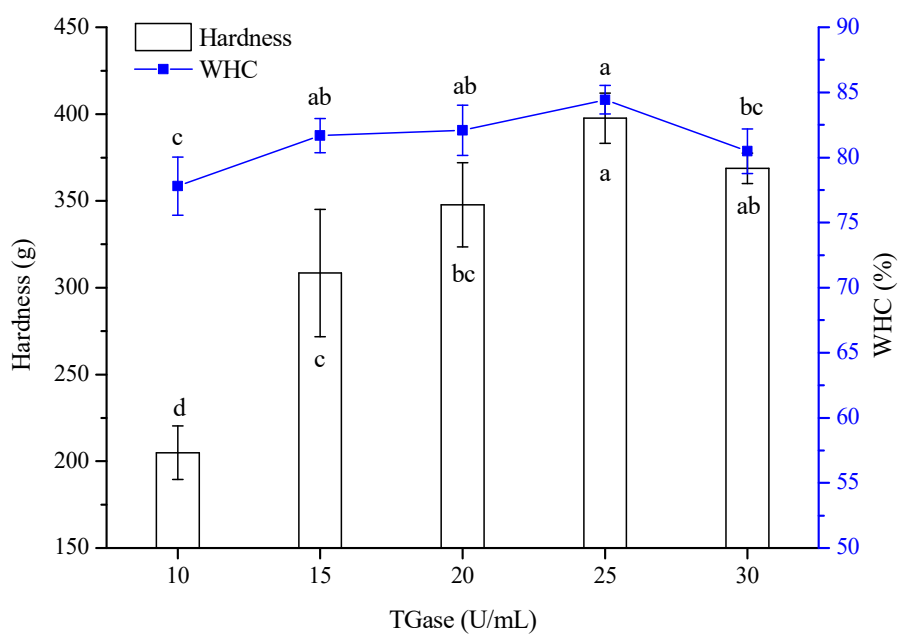

B

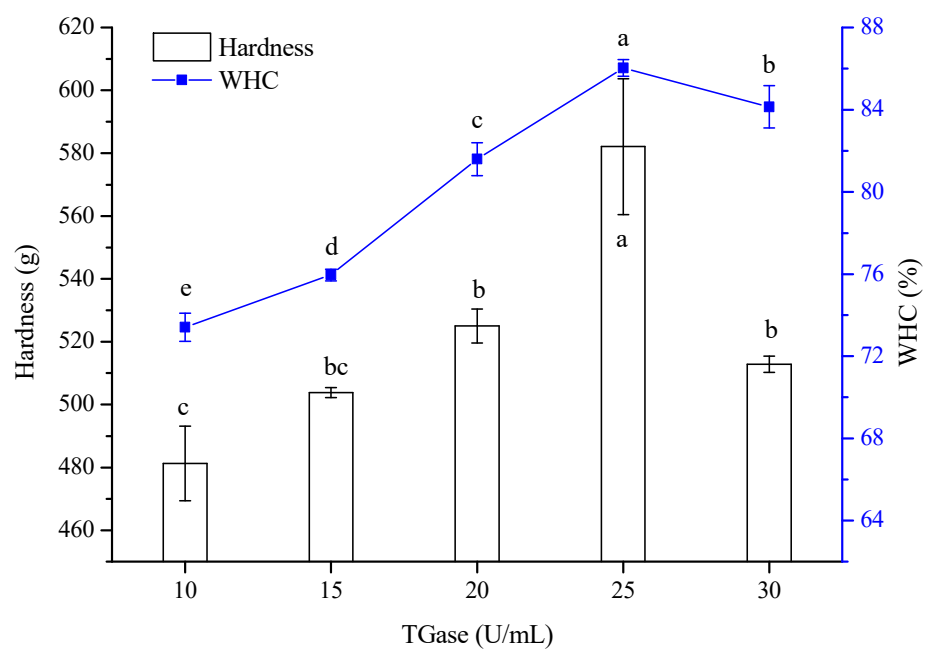

Figure 4. Effect of TGase concentration on hardness and WHC of PPI (A) and SPI (B) emulsion gels. The results are expressed as means and standard deviations of two replicates. Bars with different letters indicate significant differences $(p<0.05)$. 


\subsection{Effect of GDL Concentration on Hardness and WHC of PPI and SPI Emulsion Gels}

The mechanism of GDL-induced protein gelation is that acidification decreases the $\mathrm{pH}$ and neutralizes the surface charges of protein molecules, and a protein network is then formed by hydrophobic interactions and other intermolecular forces [25]. Figure 5 shows that the hardness and WHC of the PPI and SPI emulsion gels first increased and later decreased as a function of GDL concentration. For the PPI emulsion gel (Figure 5A), both hardness and WHC were the highest at a GDL concentration of $0.3 \%(\mathrm{w} / \mathrm{v})$. However, for the SPI emulsion gel (Figure 5B), they were the highest at a GDL concentration of $0.5 \%$ $(w / v)$. The hardness of the PPI emulsion gel was higher than that of the SPI emulsion gel at the respective optimum concentration, while the WHC of the former was significantly lower. It was reported that soymilk gels induced by GDL were usually in the $\mathrm{pH}$ range of 5.0-5.5 [26]. Ringgenberg, Alexander, and Corredig [25] found that at a $\mathrm{pH}$ of approximately 5.7 , the charge on the soymilk particles was sufficiently diminished to allow aggregation. Therefore, excessive GDL would result in a lower $\mathrm{pH}$ in the PPI and SPI emulsions, which was not suitable for gel formation. Moreover, a good linear relationship was observed between the hardness and WHC of the acid-induced emulsion gels (for peanut emulsion gel, $R^{2}=0.907$; for soybean emulsion gel, $R^{2}=0.964$ ), suggesting that gel strength played an important role in the water holding of the gels.

$\mathbf{A}$

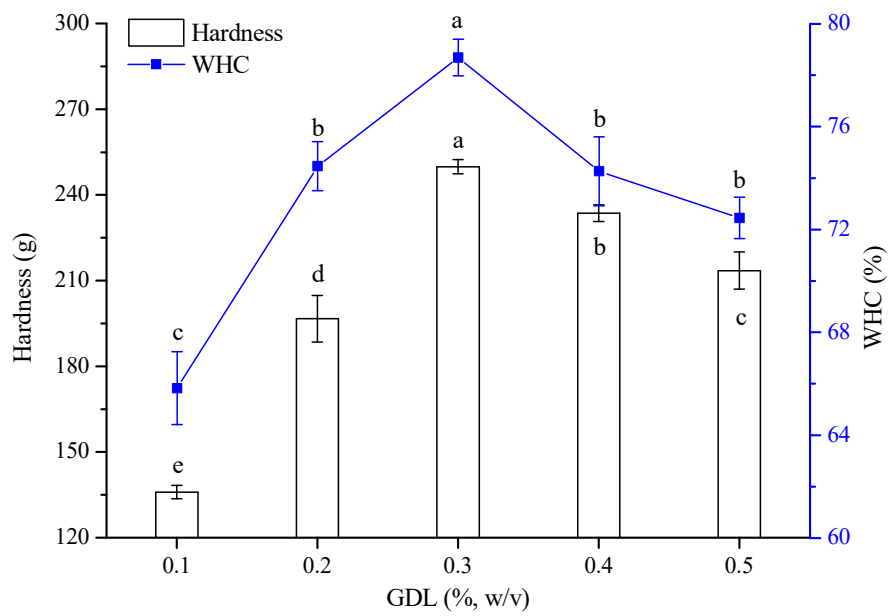

B

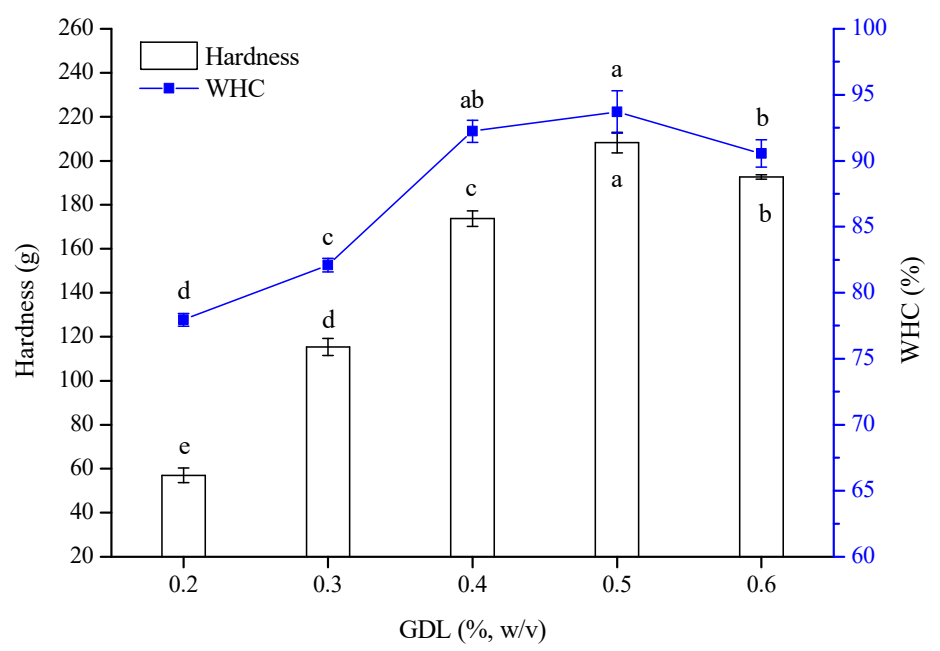

Figure 5. Effect of GDL concentration on hardness and WHC of PPI (A) and SPI (B) emulsion gels. The results are expressed as means and standard deviations of two replicates. Bars with different letters indicate significant differences $(p<0.05)$. 


\subsection{Textural Comparison of Protein-Stabilized Emulsion Gels Induced by Various Coagulants and Protein Structural Analysis}

Emulsion gels were prepared using six proteins, including PPI and its major components (arachin and conarachin) and SPI and its major components (glycinin and $\beta$-conglycinin), at a constant total protein concentration $(4 \%, \mathrm{w} / \mathrm{v})$ and oil fraction $(30 \%, \mathrm{v} / \mathrm{v})$. The optimal coagulant concentrations were selected based on the above results. As shown in Figure 6, compared to $\mathrm{CaCl}_{2}$ and GDL, the hardness of the gels formed by TGase was the highest (except arachin emulsion gel). Tang, Chen, and Foegeding [27] reported that the application of TGase exhibited a much higher potential to form SPI-stabilized emulsion gels with higher mechanical strength than that of the other two coagulants $\left(\mathrm{CaCl}_{2}\right.$ and GDL), which was consistent with our results. As listed in Table 1, since the lysine content of arachin was markedly lower than that of other proteins, it meant that the crosslinking of lysine and glutamine residues on arachin molecules might not be sufficient. On the other hand, although the lysine content of $\beta$-conglycinin and SPI was significantly higher than that of conarachin, the gel strength of the latter was higher, which suggested that there were other intermolecular forces other than the isopeptide covalent bonds in the TGase-induced emulsion gels.

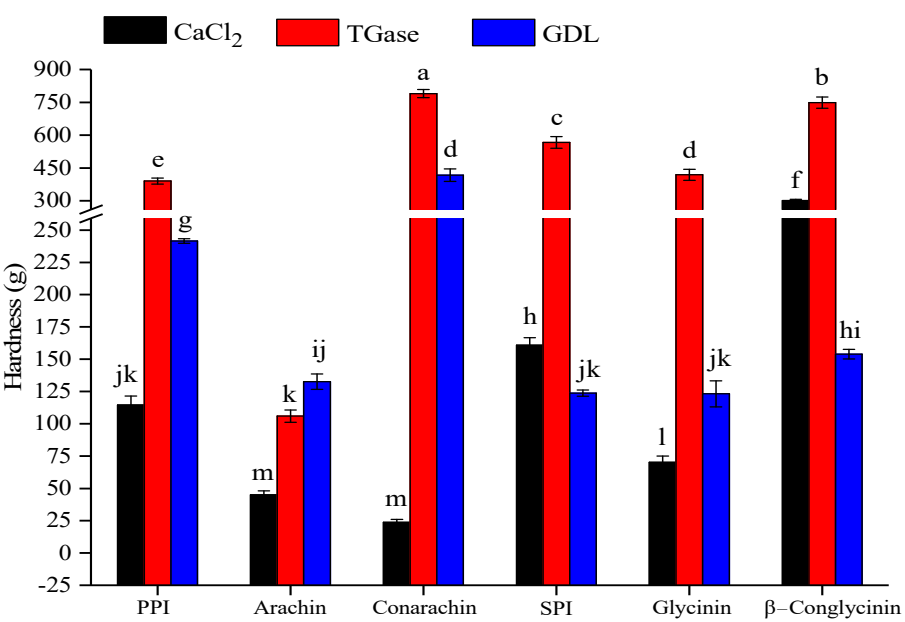

Figure 6. Textural comparison of different protein-stabilized emulsion gels induced by various coagulants. The results are expressed as means and standard deviations of three replicates. Bars with different letters indicate significant differences $(p<0.05)$.

Table 1. Amino acid composition of peanut and soy proteins including their components (Grams per $100 \mathrm{~g}$ of Protein). The results are expressed as means and standard deviations of two replicates. Bars with different letters in each line indicate significant differences $(p<0.05)$.

\begin{tabular}{ccccccc}
\hline & PPI & Arachin & Conarachin & SPI & Glycinin & $\beta-$ Conglycinin \\
\hline Asp & $12.55 \pm 0.003^{\mathrm{b}}$ & $13.12 \pm 0.39^{\mathrm{a}}$ & $12.56 \pm 0.33^{\mathrm{b}}$ & $12.36 \pm 0.82^{\mathrm{bc}}$ & $12.23 \pm 0.13^{\mathrm{cd}}$ & $12.10 \pm 0.72^{\mathrm{d}}$ \\
Thr & $2.49 \pm 0.04^{\mathrm{d}}$ & $2.18 \pm 0.01^{\mathrm{e}}$ & $2.19 \pm 0.002^{\mathrm{e}}$ & $3.25 \pm 0.09^{\mathrm{b}}$ & $3.58 \pm 0.15^{\mathrm{a}}$ & $2.8 \pm 0.02^{\mathrm{c}}$ \\
Ser & $4.77 \pm 0.01^{\mathrm{c}}$ & $4.71 \pm 0.09^{\mathrm{c}}$ & $4.68 \pm 0.02^{\mathrm{c}}$ & $5.01 \pm 0.01^{\mathrm{b}}$ & $4.99 \pm 0.13^{\mathrm{b}}$ & $5.23 \pm 0.001^{\mathrm{a}}$ \\
Glu & $21.61 \pm 0.10^{\mathrm{d}}$ & $22.64 \pm 0.06^{\mathrm{c}}$ & $23.48 \pm 0.09^{\mathrm{b}}$ & $21.81 \pm 0.09^{\mathrm{cd}}$ & $22.59 \pm 0.55^{\mathrm{c}}$ & $24.53 \pm 0.03^{\mathrm{a}}$ \\
Gly & $4.53 \pm 0.04^{\mathrm{a}}$ & $4.12 \pm 0.01^{\mathrm{c}}$ & $4.212 \pm 0.01^{\mathrm{bc}}$ & $4.12 \pm 0.01^{\mathrm{c}}$ & $4.34 \pm 0.09^{\mathrm{b}}$ & $3.31 \pm 0.08^{\mathrm{d}}$ \\
Ala & $4.02 \pm 0.02^{\mathrm{a}}$ & $4.01 \pm 0.01^{\mathrm{a}}$ & $3.14 \pm 0.003^{\mathrm{c}}$ & $3.66 \pm 0.01^{\mathrm{b}}$ & $3.70 \pm 0.08^{\mathrm{b}}$ & $3.26 \pm 0.09^{\mathrm{c}}$ \\
Cys & $0.50 \pm 0.001^{\mathrm{ab}}$ & $0.45 \pm 0.05^{\mathrm{b}}$ & $0.80 \pm 0.01^{\mathrm{a}}$ & $0.56 \pm 0.11^{\mathrm{ab}}$ & $0.57 \pm 0.17^{\mathrm{ab}}$ & $0.45 \pm 0.05^{\mathrm{b}}$ \\
Val & $4.53 \pm 0.05^{\mathrm{bc}}$ & $4.34 \pm 0.01^{\mathrm{c}}$ & $4.33 \pm 0.04^{\mathrm{c}}$ & $4.69 \pm 0.03^{\mathrm{b}}$ & $4.97 \pm 0.14^{\mathrm{a}}$ & $4.10 \pm 0.02^{\mathrm{d}}$ \\
Met & $1.27 \pm 0.002^{\mathrm{b}}$ & $0.77 \pm 0.004^{\mathrm{d}}$ & $2.47 \pm 0.02^{\mathrm{a}}$ & $1.14 \pm 0.03^{\mathrm{c}}$ & $1.2 \pm 0.02^{\mathrm{b}}$ & $0.81 \pm 0.04^{\mathrm{d}}$ \\
Ile & $3.74 \pm 0.03^{\mathrm{c}}$ & $3.57 \pm 0.02^{\mathrm{d}}$ & $3.81 \pm 0.02^{\mathrm{c}}$ & $4.83 \pm 0.04^{\mathrm{a}}$ & $4.53 \pm 0.09^{\mathrm{b}}$ & $4.75 \pm 0.04^{\mathrm{c}}$ \\
Leu & $6.89 \pm 0.03^{\mathrm{c}}$ & $6.86 \pm 0.04^{\mathrm{c}}$ & $5.95 \pm 0.01^{\mathrm{d}}$ & $7.40 \pm 0.06^{\mathrm{b}}$ & $7.47 \pm 0.03^{\mathrm{b}}$ & $7.68 \pm 0.05^{\mathrm{a}}$ \\
Tyr & $4.45 \pm 0.001^{\mathrm{b}}$ & $5.08 \pm 0.01^{\mathrm{a}}$ & $1.92 \pm 0.01^{\mathrm{e}}$ & $3.77 \pm 0.01^{\mathrm{c}}$ & $3.70 \pm 0.06^{\mathrm{c}}$ & $3.50 \pm 0.002^{\mathrm{d}}$ \\
Phe & $5.44 \pm 0.01^{\mathrm{b}}$ & $5.88 \pm 0.02^{\mathrm{a}}$ & $4.38 \pm 0.02^{\mathrm{d}}$ & $5.43 \pm 0.03^{\mathrm{b}}$ & $5.19 \pm 0.10^{\mathrm{c}}$ & $5.82 \pm 0.03^{\mathrm{a}}$ \\
His & $3.00 \pm 0.01^{\mathrm{b}}$ & $2.91 \pm 0.02^{\mathrm{b}}$ & $3.21 \pm 0.03^{\mathrm{a}}$ & $3.31 \pm 0.0001^{\mathrm{a}}$ & $2.96 \pm 0.10^{\mathrm{b}}$ & $2.91 \pm 0.03^{\mathrm{b}}$ \\
\hline
\end{tabular}


Table 1. Cont.

\begin{tabular}{ccccccc}
\hline & PPI & Arachin & Conarachin & SPI & Glycinin & $\beta-$ Conglycinin \\
\hline Lys & $3.32 \pm 0.06^{\mathrm{d}}$ & $2.29 \pm 0.01^{\mathrm{e}}$ & $5.02 \pm 0.02^{\mathrm{c}}$ & $5.98 \pm 0.05^{\mathrm{b}}$ & $5.00 \pm 0.12^{\mathrm{c}}$ & $6.26 \pm 0.05^{\mathrm{a}}$ \\
Arg & $12.57 \pm 0.03^{\mathrm{c}}$ & $13.05 \pm 0.05^{\mathrm{b}}$ & $13.98 \pm 0.04^{\mathrm{a}}$ & $7.71 \pm 0.03^{\mathrm{e}}$ & $7.60 \pm 0.06^{\mathrm{e}}$ & $8.09 \pm 0.04^{\mathrm{d}}$ \\
Pro & $4.34 \pm 0.18^{\mathrm{bc}}$ & $4.00 \pm 0.32^{\mathrm{c}}$ & $3.85 \pm 0.021^{\mathrm{c}}$ & $4.97 \pm 0.022^{\mathrm{ab}}$ & $5.33 \pm 0.08^{\mathrm{a}}$ & $4.31 \pm 0.08^{\mathrm{bc}}$ \\
\hline
\end{tabular}

Figure 7A displays the surface hydrophobicity $\left(H_{0}\right)$ values of all protein samples before and after heating treatment. Before heating, the $H_{0}$ values of conarachin and $\beta$-conglycinin were significantly higher than those of other proteins. After heating, conarachin possessed the highest $H_{0}$. The results implied that stronger hydrophobic interactions among conarachin molecules could occur during gel preparation. Figure 7B shows the exposed free sulfhydryl $(\mathrm{SH})$ contents of all protein samples before and after heating treatment. Before heating, conarachin had the highest exposed SH content (Table 1 shows the cysteine content of conarachin was the highest as well). After heating, the exposed SH content of all samples except conarachin was increased. The significant decrease in the exposed $\mathrm{SH}$ content of conarachin was probably attributed to the formation of disulfide bonds upon heating treatment. Therefore, it can be concluded that several key intermolecular forces, such as isopeptide bonds, hydrophobic interactions and disulfide bonds, together contribute to the texture of the TGase-induced emulsion gels.

$\mathbf{A}$

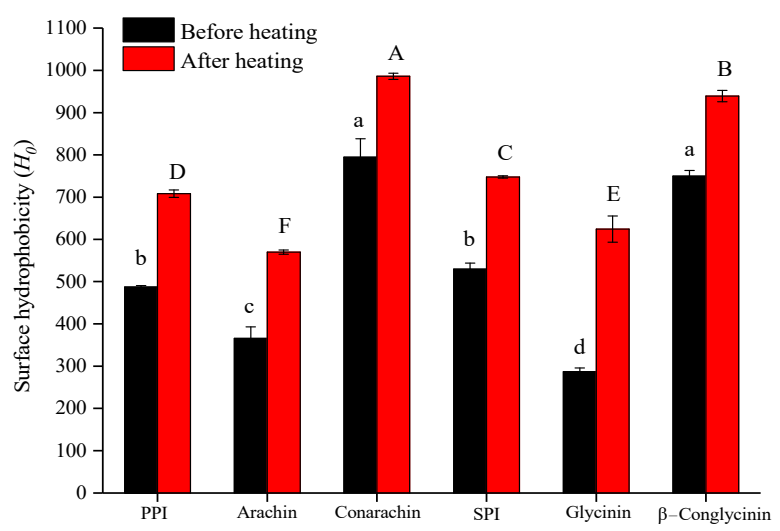

B

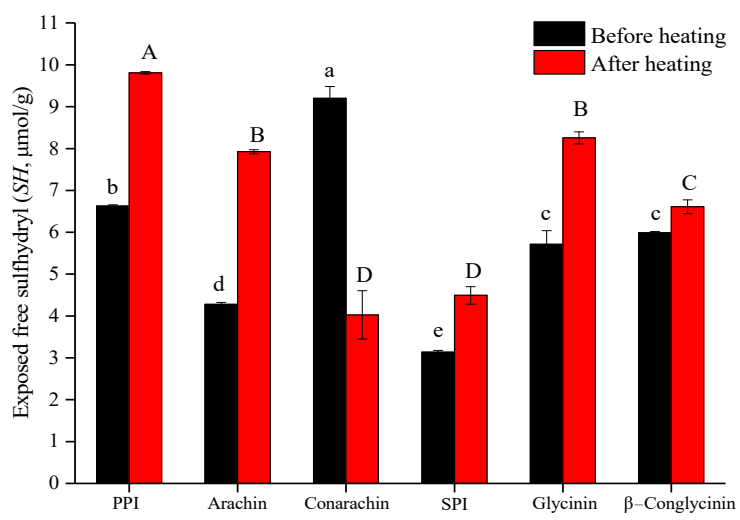

Figure 7. Surface hydrophobicity (A) and exposed free sulfhydryl contents (B) of different protein samples before and after heating treatment $\left(80^{\circ} \mathrm{C}\right.$ for $\left.30 \mathrm{~min}\right)$. The results are expressed as means and standard deviations of two replicates. Bars with different letters indicate significant differences $(p<0.05)$. 
By comparison of the $\mathrm{CaCl}_{2}$-induced emulsion gels, the hardness of the $\beta$-conglycinin gel was the highest, whereas that of the conarachin gel was the lowest. The results suggested that hydrophobic interactions and disulfide bonds were unlikely to be the key gelation forces when $\mathrm{CaCl}_{2}$ was used as the coagulant. Generally, the combination of $\mathrm{Ca}^{2+}$ and protein molecules is regarded as $\mathrm{H}^{+} / \mathrm{Ca}^{2+}$ exchange, which neutralizes electrostatic repulsion and forms salt bridges, thus allowing protein molecules to form a network [28]. From the results, it was speculated that salt bridges were not easily formed among conarachin molecules. Although the contents of dicarboxylic amino acids (glutamic acid and aspartic acid) in $\beta$-conglycinin and conarachin are similar (Table 1), the exposure of these amino acids, which can provide more protons, to the protein surface may be different, thus affecting $\mathrm{H}^{+} / \mathrm{Ca}^{2+}$ exchanges and the formation of salt bridges.

Among the emulsions using GDL as a coagulant, conarachin emulsions showed the best gelation properties. This can be explained by the fact that when the hydrogen ions released by GDL led to a decrease in the net charge of proteins, conarachin molecules could form a good network structure through strong hydrophobic interactions and the formation of more disulfide bonds. In terms of PPI and its components, the hardness of GDL-induced emulsion gels was significantly higher than that of $\mathrm{CaCl}_{2}$-induced emulsion gels. The microstructure and gelation kinetics of $\mathrm{CaCl}_{2}$-induced emulsion gels from different proteins were further compared.

\subsection{Microstructure of Different Protein-Stabilized Emulsion Gels Induced by GDL}

Generally, the structure of a protein-based emulsion gel is regarded as a composite network made up of a combination of crosslinked protein molecules and partially aggregated droplets [1]. As shown in Figure 8, the spherical oil droplets with green fluorescence were surrounded by a protein network with red fluorescence. There were significant microstructural differences among these samples. Basically, the emulsion gels stabilized by conarachin and PPI showed more homogeneous and compact structures, whereas the arachin emulsion gel exhibited an obviously porous structure and a discontinuous protein network. This result indicated that the interactions among arachin molecules were rather weaker when GDL was used as a coagulant, which may be due to their lower surface hydrophobicity and exposed free sulfhydryl content. Moreover, the particle size of the original arachin emulsion was the largest (Figure 1), and its interfacial protein concentration was the lowest (Figure 2). At the same oil content, the larger the size of the oil droplets, the smaller the number. Since the protein-coated oil droplets could act as active anchors to strengthen the gel texture [1], the decrease in the number of active anchors in the arachin emulsion gel might also be responsible for its worse network. Although the protein network of the glycinin emulsion gel seemed to be dense, it had many large oil droplets, which might weaken the structural strength of the emulsion gel.

\subsection{Microstructure of Different Protein-Stabilized Emulsion Gels Induced by GDL}

The gelation kinetics of different protein-stabilized emulsions induced by GDL were evaluated. As shown in Figure 9A, during incubation, the storage modulus $\left(\mathrm{G}^{\prime}\right)$ of all the emulsions increased sharply except for the arachin-stabilized emulsion. $G^{\prime}$ is considered the best indicator of gel structure formation and consolidation [29]. The lower $G^{\prime}$ value of the arachin-stabilized emulsion was consistent with its coarse and porous structure. In the initial stage of heating, the $G^{\prime}$ value of the glycinin emulsion increased more rapidly than those of other samples. However, after half an hour, the $G^{\prime}$ values of SPI and $\beta$-conglycinin emulsion gels became higher, which increased more dramatically in the subsequent cooling stage (Figure 9A). Tang, Luo, Liu, and Chen [8] pointed out that $\mathrm{G}^{\prime}$ progressively increased as the glycinin content increased from 0 to $100 \%$ when soy protein emulsion gels were induced by TGase at $37^{\circ} \mathrm{C}$ for $6 \mathrm{~h}$. The inconsistent results were probably attributed to the fact that the coagulant and incubation procedure used were different. It is important to note that although the $\mathrm{G}^{\prime}$ values of conarachin and PPI were much lower than those of the SPI and $\beta$-conglycinin emulsion gels according to dynamic rheological analysis, the hardness 
of the former was remarkably higher after storage overnight at $4{ }^{\circ} \mathrm{C}$ (Figure 6). The results imply that the enhancement of intermolecular interactions by storage in conarachin and PPI emulsion gels was higher.
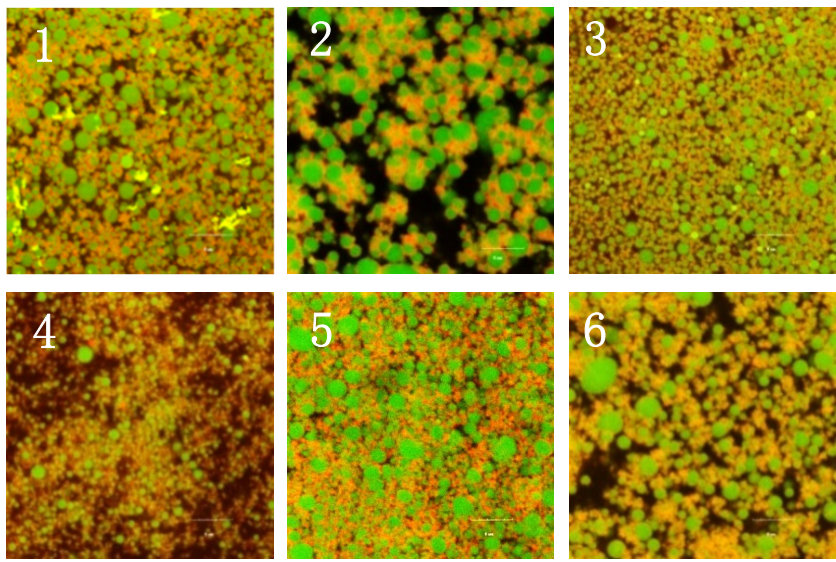

Figure 8. CLSM micrographs of emulsion gel samples induced by GDL, the bars indicate $5 \mu \mathrm{m}$ in length, oil droplets (green), protein networks (red). 1, PPI; 2, Arachin; 3, Conarachin; 4, SPI; 5, Glycinin; 6, $\beta$-Conglycinin.

$\mathbf{A}$

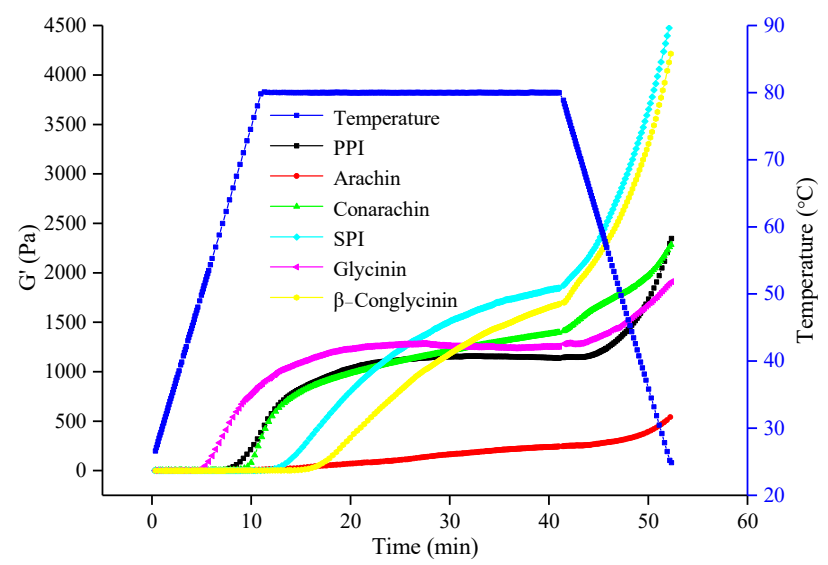

B

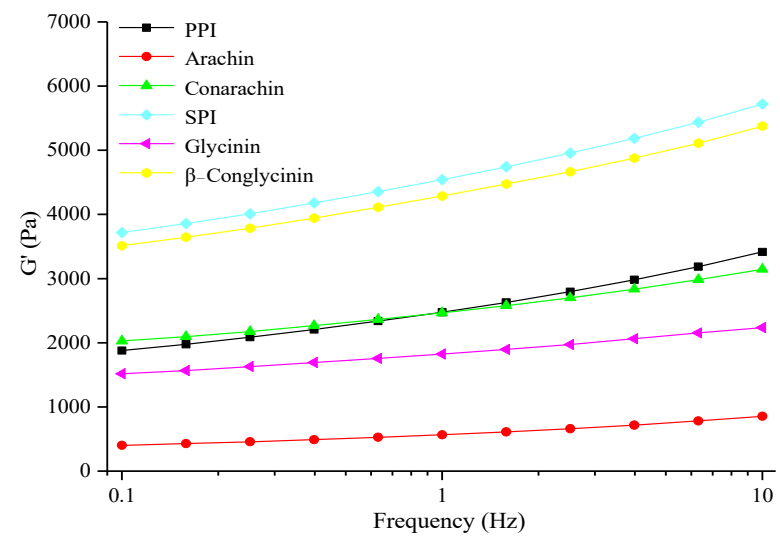

Figure 9. (A) Evolution of storage modulus $\left(\mathrm{G}^{\prime}\right)$ of emulsion gel samples induced by GDL during heating and cooling cycle. (B) Frequency dependence of $\mathrm{G}^{\prime}$ the correspondingly formed emulsion gels after cooling. 
Frequency sweep experiments on the corresponding emulsion gels were further carried out, which could reflect the interactive force nature in the formed emulsion gels. As shown in Figure 9B, the $\mathrm{G}^{\prime}$ values of arachin and glycinin emulsion gels did not exhibit frequency dependency in the range of $0.1-10 \mathrm{~Hz}$, indicating that these emulsion gels are mainly formed through covalent "chemical crosslinks" [30]. However, in the case of SPI, PPI, $\beta$-conglycinin and conarachin emulsion gels, their $G^{\prime}$ values gradually increased with increasing frequency, indicating that these emulsion gels are mainly formed through noncovalent "physical crosslinks", which are breakable or deformable [31]. Wang et al. [22] and Tang, Yang, Liu, and Chen [8] reported similar results when using various coagulants.

\section{Conclusions}

The various coagulant concentrations were optimized for peanut and soy proteinstabilized emulsion gels. The soy protein gel generally had better WHC than the peanut protein gel. Among the six proteins (PPI, arachin, conarachin, SPI, glycinin and $\beta$-conglycinin), when $\mathrm{CaCl}_{2}$ was used as a coagulant, the hardness of the emulsion gel from conarachin was the lowest. However, when TGase and GDL were used as coagulants, the conarachin emulsion gel had the strongest texture. The GDL-induced conarachin emulsion gel showed more homogeneous and compact structures. Protein structural analysis showed that conarachin had the highest surface hydrophobicity and exposed free sulfhydryl content, which should be responsible for the better texture of the conarachin-stabilized emulsion gel. This work reveals that conarachin has good application potential in the preparation of emulsion gels using TGase and GDL as coagulants.

\section{Materials and Methods}

\subsection{Materials}

Peanut seeds (4.53\% water, $49.81 \%$ oil and $25.07 \%$ protein), defatted soybean meal and soybean oil were purchased from the local market. PPI (protein content: $80.15 \pm 1.69 \%$ ) was prepared according to the procedure of alkali-soluble and acid precipitation in our lab [4]. The oil content of the peanut seeds was determined by the Soxhlet extraction method (AOCS Official Method, Ba 3-38, 1998). The protein contents of the peanut seeds and PPI were determined by the Kjeldahl method $(\mathrm{N} \times 5.46)$ (AOCS Official Method, Ba 4a-38, 1998). 8Anilinonaphthalene-sulphonic acid (ANS), 5,5'-dithiobis (2-nitrobenzoic acid) (DTNB), Nile red and Fluorescein isothiocyanate (FITC) were purchased from Yuanye Bio-Technology Co., Ltd. (Shanghai, China). GDL was purchased from Macklin Biochemical Co., Ltd. (Shanghai, China). The microbial TGase used in this study was Baibang TGase (a solid powder mixed with maltodextrin, with an enzyme activity of $242 \mathrm{U} / \mathrm{g}$ ) donated by Qingrui Food Technology Co., Ltd. (Shanghai, China). All other reagents were of analytical grade.

\subsection{Extraction of Arachin and Conarachin from PPI}

PPI was mixed with 3 times phosphate buffer solution $(0.3 \mathrm{~mol} / \mathrm{L}, \mathrm{pH} 7.5)$, which was stirred at room temperature for $1 \mathrm{~h}$, followed by centrifugation $(4000 \mathrm{r} / \mathrm{min}, 15 \mathrm{~min}$ ) at room temperature with a centrifuge (GL-20G, Anting Instrument Co, Ltd., Shanghai, China) to discard the insoluble matter. The supernatant was treated in two ways to obtain arachin and conarachin. (1) The supernatant was placed overnight at $2{ }^{\circ} \mathrm{C}$ and then centrifuged $(8000 \mathrm{r} / \mathrm{min}, 20 \mathrm{~min})$ at $2{ }^{\circ} \mathrm{C}$. The precipitated arachin was freeze-dried and stored in a desiccator. (2) Ammonium sulfate was added to the supernatant until its saturation reached $60 \%$. The solution was stirred evenly and then centrifuged ( $8000 \mathrm{r} / \mathrm{min}, 20 \mathrm{~min})$. Ammonium sulfate was added to the supernatant until its saturation reached $85 \%$. The solution was stirred and then centrifuged as described above. The precipitate was dialyzed to remove ammonium sulfate, followed by freeze drying to obtain conarachin. The protein contents of arachin and conarachin were $84.45 \pm 0.51 \%$ and $89.85 \pm 0.98 \%$, respectively. 


\subsection{Extraction of Soy Protein Isolates (SPI), Glycinin and $\beta$-Conglycinin from Defatted Soybean Meal}

SPI was extracted according to the alkali-soluble and acid precipitation procedure. Soy glycinin and $\beta$-conglycinin were prepared according to the process reported by Nagano, Hirotsuka, and Mori [32]. The specific steps were as follows.

(1) Defatted soybean meal was mixed with 10 times deionized water, and the $\mathrm{pH}$ value of the dispersions was adjusted to 8.0 with $2 \mathrm{M} \mathrm{NaOH}$. After stirring for $1 \mathrm{~h}$ at room temperature, the suspension was shaken in a water bath shaker (SHZ-88, Jiangsu Instrument Co., Ltd., Jingyi, China) at $50{ }^{\circ} \mathrm{C}$ for $30 \mathrm{~min}$. After centrifugation $(4000 \mathrm{r} / \mathrm{min}$, $15 \mathrm{~min}$ ), the precipitate was discarded, and the $\mathrm{pH}$ of the supernatant was then adjusted to 4.5 with $2 \mathrm{M} \mathrm{HCl}$ to precipitate the soy proteins. The precipitate was then washed with deionized water twice to remove most of $\mathrm{HCl}$. The precipitated proteins were freeze-dried as SPI (protein content: $83.60 \pm 1.0 \%$ ).

(2) Sodium bisulfite was added to the above supernatant to achieve a final concentration $(0.98 \mathrm{~g} / \mathrm{L})$, and its $\mathrm{pH}$ was adjusted to 6.4 with $2 \mathrm{M} \mathrm{HCl}$. The protein solution was then placed overnight at $4{ }^{\circ} \mathrm{C}$, followed by centrifugation $\left(4^{\circ} \mathrm{C}, 8000 \mathrm{r} / \mathrm{min}, 20 \mathrm{~min}\right)$. The obtained precipitate was freeze-dried as glycinin $(87.94 \pm 0.66 \%)$. Next, sodium chloride was added to the obtained supernatant to achieve a final concentration $(0.25 \mathrm{~mol} / \mathrm{L})$, and its $\mathrm{pH}$ was adjusted to 5.0 with $2 \mathrm{M} \mathrm{HCl}$. The protein solution was then centrifuged at $8000 \mathrm{r} / \mathrm{min}$ for $20 \mathrm{~min}$. The precipitate was discarded. Twice the volume of ice water was added to the supernatant, and the $\mathrm{pH}$ was adjusted to 4.8 , followed by centrifugation $\left(4{ }^{\circ} \mathrm{C}, 8000 \mathrm{r} / \mathrm{min}, 20 \mathrm{~min}\right)$. The obtained precipitate was freeze-dried as $\beta$-conglycinin $(82.37 \pm 0.8 \%)$.

\subsection{Preparation of Different Protein-Stabilized Emulsions by Ultrasonic Method}

First, protein suspensions $(4 \%, \mathrm{w} / \mathrm{v})$ were prepared by dispersing the protein samples in distilled water into a $200-\mathrm{mL}$ beaker, which was gently stirred at $25^{\circ} \mathrm{C}$ until they were sufficiently dissolved. The $\mathrm{pH}$ of the dispersions was adjusted to 7.0 with $2 \mathrm{M} \mathrm{NaOH}$. Then, soybean oil $(30 \%, \mathrm{v} / \mathrm{v})$ was added to the protein suspensions. The mixture was processed at 10,000 rpm for $2 \mathrm{~min}$ by a high-shear probe homogenizer (Model FA25, Fluko Equipment Shanghai Co., Ltd., Shanghai, China). The obtained coarse emulsions were further treated by an ultrasonic processor (Scientz-IID, NingBo Scientz Biotechnology Co., Ltd., Ningbo, China) with an 80-170 $\mu \mathrm{m}$ of amplitude to prepare the final emulsions. The titanium probe used had a $0.636-\mathrm{cm}$ diameter. The samples were sonicated $(20 \mathrm{~min}$, pulse duration of $3 \mathrm{~s}$ and off time of $2 \mathrm{~s}$ ) at $300 \mathrm{~W}$. The sample temperature was kept below $30{ }^{\circ} \mathrm{C}$ in an ice-water bath.

\subsection{Emulsion Characterization}

The particle size of the emulsion samples was measured according to our previous work [4]. The surface protein concentration of the emulsion samples was measured according to the method of Zhang and $\mathrm{Lu}$ [33].

\subsection{Preparation of Emulsion Gels}

All emulsion samples were prepared at a constant total protein concentration $(4 \%$, $\mathrm{w} / \mathrm{v})$ and oil fraction $(30 \%, \mathrm{v} / \mathrm{v})$. The emulsion gels were prepared using $\mathrm{CaCl}_{2}$, TGase and GDL were used as the coagulants in 50 -mL beakers.

(1) $\mathrm{CaCl}_{2}$-induced gels. $\mathrm{CaCl}_{2}$ was added to the emulsion sample $(20 \mathrm{~mL})$ to achieve final concentrations of $0.1,0.15,0.2,0.25$, and $0.3 \mathrm{~g} / \mathrm{dL}$. The mixture was gently stirred and then heated for $30 \mathrm{~min}$ in an $80^{\circ} \mathrm{C}$ water bath to form a gel. The gel was then cooled immediately in cold water and stored overnight at $4{ }^{\circ} \mathrm{C}$.

(2) TGase-induced gels. TGase was added to the emulsion sample $(20 \mathrm{~mL})$ to achieve final concentrations of 10, 15, 20, 25 and $30 \mathrm{U} / \mathrm{mL}$. The mixture was stirred for $3 \mathrm{~min}$ at room temperature, followed by incubation in a $45{ }^{\circ} \mathrm{C}$ water bath for $6 \mathrm{~h}$ to form gels. Then, the gels were cooled immediately and stored overnight at $4{ }^{\circ} \mathrm{C}$. 
(3) GDL-induced gels. GDL was added to the emulsion sample (20 mL) to achieve a final concentration $(0.1 \%, 0.2 \%, 0.3 \%, 0.4 \%, 0.5 \%$ and $0.6 \%(\mathrm{w} / \mathrm{v}))$. The mixture was gently stirred and then heated for $30 \mathrm{~min}$ in an $85{ }^{\circ} \mathrm{C}$ water bath to form a gel. The gel was then cooled immediately in cold water and stored overnight at $4{ }^{\circ} \mathrm{C}$. The texture and WHC of the emulsion gels were analyzed to establish the concentrations of coagulants.

\subsection{Emulsion Gel Characterization}

4.7.1. Dynamic Viscoelastic Measurement

Dynamic viscoelastic measurements of emulsion gels were determined at a $1.0 \%$ strain according to our previous work [4]. The storage modulus ( $\mathrm{G}^{\prime}$ ) and loss modulus ( $\mathrm{G}^{\prime \prime}$ ) were recorded during heating and cooling cycles at a fixed frequency of $1.0 \mathrm{~Hz}$. Then, the experiment was oscillated at $25^{\circ} \mathrm{C}$ with a frequency from 0.1 to $10.0 \mathrm{~Hz} . \mathrm{G}^{\prime}$ and $\mathrm{G}^{\prime \prime}$ were recorded.

\subsubsection{Emulsion Gel Textural Analysis}

The texture of the emulsion gels was analyzed by a texture analyzer (TA-TX2i, Stable Micro System Ltd., Godalming, England) with a cylinder probe (P/0.5) according to our previous work [4].

\subsubsection{Emulsion Gel Water-Holding Capacity (WHC)}

The emulsion gel samples (5.0-6.0 g each) were transferred to 10-mL centrifuge tubes and centrifuged $\left(4^{\circ} \mathrm{C}, 8000 \mathrm{r} / \mathrm{min}, 20 \mathrm{~min}\right)$. The water on top of the tubes was carefully removed using filter paper. The tubes containing the emulsion gels before and after centrifugation were weighed. The WHC was calculated using Equation (1):

$$
\mathrm{WHC}(\%)=\left(\mathrm{W}_{1}-\mathrm{W}\right) /\left(\mathrm{W}_{2}-\mathrm{W}\right) \times 100 \%
$$

where $W$ is the weight of the centrifuge tube; $W_{1}$ is the total weight of the centrifuge tube and emulsion gel after centrifugation; and $W_{2}$ is the total weight of the centrifuge tube and emulsion gel before centrifugation.

\subsubsection{Confocal Laser Scanning Microscope (CLSM)}

A confocal laser scanning microscope (FV3000, Olympus, Tokyo, Japan) equipped with a $100 \times$ objective lens (oil immersion) was applied to observe the microstructure of GDL-induced emulsion gels. The assay procedure was performed according to our previous work [4].

\subsection{Protein Structural Properties \\ 4.8.1. Surface Hydrophobicity}

The surface hydrophobicity $\left(H_{0}\right)$ of protein samples was determined using ANS as the fluorescence probe according to our previous work [4].

\subsubsection{Exposed Free SH Content}

The exposed free $S H$ content of the protein samples was determined using the 5,5'dithiobis (2-nitrobenzoic acid) (DTNB) reagent according to the method of Zhang, Yan, Jiang, and Ding [34] with modifications. Ellman's reagent was prepared by dissolving $40 \mathrm{mg}$ of DTNB reagent in $10 \mathrm{~mL}$ of tris-glycine buffer ( $\mathrm{pH} 8.0$ ) containing $0.086 \mathrm{M}$ Tris, $0.09 \mathrm{M}$ glycine and $4 \mathrm{mM}$ EDTA. Protein samples $(30 \mathrm{mg})$ were solubilized in $10 \mathrm{~mL}$ of Tris-glycine buffer, followed by centrifugation at $5000 \mathrm{r} / \mathrm{min}$ for $15 \mathrm{~min}$. The protein content of the supernatant was determined by the method of Lowry, Rosebrough, Farr, and Randall [35]. Then, $50 \mu \mathrm{L}$ of Ellman's reagent was added to $3 \mathrm{~mL}$ of supernatant. After incubation at room temperature for $5 \mathrm{~min}$, the absorbance of the suspension was read at 
$412 \mathrm{~nm}$. The buffer was used as a control blank. The $S H$ content was calculated using Equation (2):

$$
S H(\mu \mathrm{mol} / \mathrm{g})=\frac{73.53 \mathrm{~A}}{\mathrm{C}}
$$

where $\mathrm{A}$ is the absorbance at $412 \mathrm{~nm}$ and $\mathrm{C}$ is the protein concentration of the supernatant (mg/gL).

\subsubsection{Amino Acid Analysis}

Seventeen amino acids (except for tryptophan) were analyzed using an automated amino acid analyzer (S433D, Sykam, Germany). After hydrolyzing the protein samples at $110{ }^{\circ} \mathrm{C}$ for $24 \mathrm{~h}$ with $6 \mathrm{M} \mathrm{HCl}$, RP-HPLC analysis with online derivation was carried out.

\subsection{Statistical Analysis}

The reported values are the means for at least two replicates. The significant difference $(p<0.05)$ between various samples was analyzed through ANOVA by Duncan's multiple range tests.

Author Contributions: Conceptualization, S.Z. (Shaobing Zhang); methodology, S.Z. (Shaobing Zhang) and Y.J.; formal analysis, Y.J.; visualization, Y.J.; investigation, Y.J., S.Z. (Shuyan Zhang) and L.C.; writing-original draft preparation, S.Z. (Shaobing Zhang); supervision, S.Z. (Shaobing Zhang); funding acquisition, S.Z. (Shaobing Zhang). All authors have read and agreed to the published version of the manuscript.

Funding: This work is supported by the National Natural Science Foundation of China (Grant No. 32072168 and U21A20270)

Institutional Review Board Statement: Not applicable.

Informed Consent Statement: Not applicable.

Data Availability Statement: The data presented in this study are available on request.

Conflicts of Interest: The authors declare no conflict of interest.

\section{References}

1. Dickinson, E. Emulsion gels: The structuring of soft solids with protein-stabilized oil droplets. Food Hydrocoll. 2012, 28, 224-241. [CrossRef]

2. Li, X.M.; Meng, R.; Xu, B.C.; Zhang, B. Investigation of the fabrication, characterization, protective effect and digestive mechanism of a novel Pickering emulsion gels. Food Hydrocoll. 2021, 117, 106708. [CrossRef]

3. Lin, D.Q.; Kelly, A.L.; Miao, S. Preparation, structure-property relationships and applications of different emulsion gels: Bulk emulsion gels, emulsion gel particles, and fluid emulsion gels. Trends Food Sci. Technol. 2020, 102, 123-137. [CrossRef]

4. Jiang, Y.S.; Zhang, S.B.; Zhang, S.Y.; Peng, Y.X. Comparative study of high-intensity ultrasound and high-pressure homogenization on physicochemical properties of peanut protein-stabilized emulsions and emulsion gels. J. Food Process Eng. 2021, 44 , e13710. [CrossRef]

5. Hu, S.; Wu, J.; Zhu, B.; Du, M.; Wu, C.; Yu, C.; Song, L.; Xu, X. Low oil emulsion gel stabilized by defatted Antarctic krill (Euphausia superba) protein using high-intensity ultrasound. Ultrason. Sonochemistry 2021, 70, 105294. [CrossRef] [PubMed]

6. Cheng, Y.; Donkor, P.O.; Ren, X.; Wu, J.; Agyemang, K.; Ayim, I.; Ma, H. Effect of ultrasound pretreatment with mono-frequency and simultaneous dual frequency on the mechanical properties and microstructure of whey protein emulsion gels. Food Hydrocoll. 2019, 89, 434-442. [CrossRef]

7. Paglarini, C.S.; Martini, S.; Pollonio, M.A.R. Physical properties of emulsion gels formulated with sonicated soy protein isolate. Int. J. Food Sci. Technol. 2019, 54, 451-459. [CrossRef]

8. Tang, C.H.; Luo, L.J.; Liu, F.; Chen, Z. Transglutaminase-set soy globulin-stabilized emulsion gels: Influence of soy $\beta$-conglycinin/glycinin ratio on properties, microstructure and gelling mechanism. Food Res. Int. 2013, 51, 804-812. [CrossRef]

9. Yan, C.; Fu, D.; McClements, D.J.; Xu, P.; Zou, L.; Zhu, Y.; Cheng, C.; Liu, W. Rheological and microstructural properties of cold-set emulsion gels fabricated from mixed proteins: Whey protein and lactoferrin. Food Res. Int. 2019, 119, 315-324. [CrossRef]

10. Lu, Y.; Mao, L.K.; Zheng, H.X.; Chen, H.Q.; Gao, Y.X. Characterization of beta-carotene loaded emulsion gels containing denatured and native whey protein. Food Hydrocoll. 2020, 102, 105600. [CrossRef]

11. Lu, Y.; Zhang, Y.; Yuan, F.; Gao, Y.; Mao, L. Emulsion gels with different proteins at the interface: Structures and delivery functionality. Food Hydrocoll. 2021, 116, 106637. [CrossRef] 
12. Du, Y.; Wang, Q.; Liu, H.Z.; Wang, L.; Liu, L. Major protein fractions and subunit contents in peanut from different cultivars. Food Sci. 2013, 34, 42-46. (In Chinese)

13. Yamada, T.; Aibara, S.; Morita, Y. Accumulation pattern of arachin and its subunits in maturation of groundnut seeds. Plant Cell Physiol. 1980, 21, 1217-1226. [CrossRef]

14. Monteiro, P.V.; Prakash, V. Effect of proteases on arachin, conarachin I, and conarachin II from peanut (Arachis hypogaea L.). J. Agric. Food Chem. 1994, 42, 268-273. [CrossRef]

15. Monteiro, P.V.; Prakash, V. Functional properties of homogeneous protein fractions from peanut (Arachis hypogaea L.). J. Agric. Food Chem. 1994, 42, 274-278. [CrossRef]

16. Liu, Y.; Zhao, G.; Su, X. Functional and confomational properties of arachin and conarachin. Mod. Food Sci. Technol. 2013, 29, 2095-2101. (In Chinese)

17. Feng, X.L.; Liu, H.Z.; Shi, A.M.; Liu, L.; Wang, Q.; Adhikari, B. Effects of transglutaminase catalyzed crosslinking on physicochemical characteristics of arachin and conarachin-rich peanut protein fractions. Food Res. Int. 2014, 62, 84-90. [CrossRef]

18. Sun, X.; Zhang, W.; Zhang, L.; Tian, S.; Chen, F. Molecular and emulsifying properties of arachin and conarachin of peanut protein isolate from ultrasound-assisted extraction. LWT-Food Sci. Technol. 2020, 132, 109790. [CrossRef]

19. Hu, X.; Amakye, W.K.; He, P.; Wang, M.; Ren, J. Effects of microfluidization and transglutaminase cross-linking on the conformations and functional properties of arachin and conarachin in peanut. LWT-Food Sci. Technol. 2021, 146, 111438. [CrossRef]

20. Puppo, M.C.; Speroni, F.; Chapleau, N.; de Lamballerie, M.; Anon, M.C.; Anton, M. Effect of high-pressure treatment on emulsifying properties of soybean proteins. Food Hydrocoll. 2005, 19, 289-296. [CrossRef]

21. Sok Line, V.L.; Remondetto, G.E.; Subirade, M. Cold gelation of $\beta$-lactoglobulin oil-in-water emulsions. Food Hydrocoll. 2005, 19, 269-278. [CrossRef]

22. Wang, X.; Zeng, M.; Qin, F.; Adhikari, B.; He, Z.; Chen, J. Enhanced $\mathrm{CaSO}_{4}$-induced gelation properties of soy protein isolate emulsion by pre-aggregation. Food Chem. 2018, 242, 459-465. [CrossRef]

23. Joseph, D.; Lanier, T.C.; Hamann, D.D. Temperature and $\mathrm{pH}$ affect transglutaminase-catalyzed setting of crude fish actomyosin J. Food Sci. 1994, 59, 1018-1023. [CrossRef]

24. Alavi, F.; Emam-Djomeh, Z.; Salami, M.; Mohammadian, M. Effect of microbial transglutaminase on the mechanical properties and microstructure of acid-induced gels and emulsion gels produced from thermal denatured egg white proteins. Int. J. Biol. Macromol. 2020, 153, 523-532. [CrossRef]

25. Ringgenberg, E.; Alexander, M.; Corredig, M. Effect of concentration and incubation temperature on the acid induced aggregation of soymilk. Food Hydrocoll. 2013, 30, 463-469. [CrossRef]

26. Kohyama, K.; Nishinari, K. Rheological studies on the gelation process of soybean 7S and $11 \mathrm{~S}$ proteins in the presence of glucono-delta-lactone. J. Agric. Food Chem. 1993, 41, 8-14. [CrossRef]

27. Tang, C.H.; Chen, L.; Foegeding, E.A. Mechanical and water-holding properties and microstructure of soy protein isolate emulsion gels induced by $\mathrm{CaCl}_{2}$, glucono-d-lactone (GDL) and transglutaminase: Influence of thermal treatments before and/or after emulsification. J. Agric. Food Chem. 2011, 59, 4071-4077. [CrossRef] [PubMed]

28. Canabady-Rochelle, L.S.; Sanchez, C.; Mellema, M.; Banon, S. Study of calcium-soy protein interactions by isothermal titration calorimetry and pH Cycle. J. Agric. Food Chem. 2009, 57, 5939-5947. [CrossRef] [PubMed]

29. Maltais, A.; Remondetto, G.E.; Gonzalez, R.; Subirade, M. Formation of soy protein isolate cold-set gels: Protein and salt effects. J. Food Sci. 2005, 70, C67-C73. [CrossRef]

30. Dicksinson, E.; Yamamoto, Y. Rheology of milk protein gels and protein-stabilized emulsion gels cross-linked with transglutaminase. J. Agric. Food Chem. 1996, 44, 1371-1377. [CrossRef]

31. Kohyama, K.; Sano, Y.; Doi, E. Rheological characteristics and gelation mechanism of tofu (soybean curd). J. Agric. Food Chem. 1995, 43, 1808-1812. [CrossRef]

32. Nagano, T.; Hirotsuka, M.; Mori, H. Dynamic viscoelastic study on the gelatin of 7S globulin from soybeans. J. Agric. Food Chem 1992, 40, 941-944. [CrossRef]

33. Zhang, S.B.; Lu, Q.Y. Characterizing the structural and surface properties of proteins isolated before and after enzymatic demulsification of the aqueous extract emulsion of peanut seeds. Food Hydrocoll. 2015, 47, 51-60. [CrossRef]

34. Zhang, S.B.; Yan, D.Q.; Jiang, Y.S.; Ding, C.H. Competitive displacement of interfacial soy proteins by Tween 20 and its effect on the physical stability of emulsions. Food Hydrocoll. 2021, 113, 106515. [CrossRef]

35. Lowry, O.H.; Rosebrough, N.J.; Farr, A.L.; Randall, R.J. Protein measurement with the folin phenol reagent. J. Biol. Chem. 1951, 193, 265-275. [CrossRef] 